\title{
Isolation and Characterization of Lactobacillus brevis Phages
}

\author{
Marine Feyereisen ${ }^{1}{ }^{\complement}$, Jennifer Mahony ${ }^{1,2}$, Gabriele A. Lugli ${ }^{3}$, Marco Ventura ${ }^{3}$, Horst Neve ${ }^{4}{ }^{\circledR}$, \\ Charles M. A. P. Franz ${ }^{4}$, Jean-Paul Noben $\left.{ }^{5}{ }^{(}\right)$, Tadhg O'Sullivan ${ }^{6}$ and Douwe van Sinderen $1,2, *$ \\ 1 School of Microbiology, University College of Cork, T12 YT20 Cork, Ireland; 116221209@umail.ucc.ie (M.F.); \\ J.Mahony@ucc.ie (J.M.) \\ 2 APC Microbiome Ireland, University College of Cork, T12 YT20 Cork, Ireland \\ 3 Laboratory of Probiogenomics, Department of Chemistry, Life Sciences, and Environmental Sustainability, \\ University of Parma, 43124, Parma, Italy; gabrieleandrea.lugli@unipr.it (G.A.L.); \\ marco.ventura@unipr.it (M.V.) \\ 4 Department Microbiology and Biotechnology, Federal Research Centre of Nutrition and Food, \\ Max Rubner-Institut, 24103, Kiel, Germany; horst.neve@mri.bund.de (H.N.); \\ charles.franz@mri.bund.de (C.M.A.P.F.) \\ 5 Department Physiology Biochemistry and Immunology, Biomedical Research Institute, Hasselt University, \\ B-3590 Diepenbeek, Belgium; jeanpaul.noben@uhasselt.be \\ 6 HEINEKEN Global Innovation and Research, Heineken Supply Chain B.V, 2382 Zoeterwoude, \\ The Netherlands; Tadhg.OSullivan@heineken.com \\ * Correspondence: d.vansinderen@ucc.ie; Tel.: +353-21-4901365
}

Received: 26 March 2019; Accepted: 24 April 2019; Published: 26 April 2019

check for updates

\begin{abstract}
Lactobacillus brevis has been widely used in industry for fermentation purposes. However, it is also associated with the spoilage of foods and beverages, in particular, beer. There is an increasing demand for natural food preservation methods, and in this context, bacteriophages possess the potential to control such spoilage bacteria. Just a few studies on phages infecting Lactobacillus brevis have been performed to date and in the present study, we report the isolation and characterization of five virulent phages capable of infecting $L b$. brevis strains. The analysis reveals a high diversity among the isolates, with members belonging to both, the Myoviridae and Siphoviridae families. One isolate, designated phage 3-521, possesses a genome of $140.8 \mathrm{~kb}$, thus representing the largest Lb. brevis phage genome sequenced to date. While the isolated phages do not propagate on $L b$. brevis beer-spoiling strains, phages showed activity against these strains, impairing the growth of some Lb. brevis strains. The results highlight the potential of bacteriophage-based treatments as an effective approach to prevent bacterial spoilage of beer.
\end{abstract}

Keywords: Lactobacillus brevis; bacteriophage; virulent; beer; fermentation; genomic and proteomic analysis

\section{Introduction}

Lactobacillus brevis is a Gram-positive, heterofermentative lactic acid bacterium (LAB) that grows optimally at $30{ }^{\circ} \mathrm{C}$ and $\mathrm{pH} 4-6$ [1]. Lb. brevis is used in the production of fermented foods [1,2]. Recently strains of this species have also been characterized as "probiotic" potentially promoting gut microbiota fitness and consumer health [2,3]. Conversely, $L b$. brevis strains are also associated with food and beverage spoilage, particularly that of beer [4,5]. Beer is generally regarded as a harsh environment for microorganisms [5,6]. Indeed, the reduced availability of oxygen and nutrients coupled with the presence of an acidic environment, ethanol, carbon dioxide and hop compounds represent considerable challenges to microbial growth $[5,6]$. Despite the nature of beer and the array of 
antimicrobial compounds it contains, bacterial strains have emerged that can tolerate and grow in the presence of these hurdles [6,7]. This bacterial growth is mostly attributed to certain LAB, especially $L b$. brevis and may result in the production of malodorous compounds, acidity and/or turbidity, thereby negatively impacting on the organoleptic properties of the final product $[5,7,8]$. Current approaches to increase the safety of beer include pasteurization, filtration, suitable materials and process packaging, strict cleaning and sanitation practices [7]. However, non-pasteurized beer products are in high demand, thus increasing the risk of microbial spoilage, for example by LAB, in particular when filtration cannot be applied [9]. The overuse of chemical sanitizers has led to an increase in biocidal-resistance of these food-spoilage bacteria [10]. Moreover, chemical sanitizers may be corrosive and/or toxic, thereby limiting the range of sanitizers that may be employed safely in industry. Various alternative strategies have been implemented to control bacterial spoilage using antimicrobials such as bacteriocins [11-13], and bioremediation using bacteriophages has re-appeared as a potential procedure for limiting spoilage bacteria in food and beverages [14-17]. Bacteriophages present an interesting bio-remediation approach, because they are naturally ubiquitous and specific to their bacterial host [18]. The impact of bacteriophages in preventing/limiting spoilage has been thoroughly explored in the case of food fermentation applications [16], although at the same time the prevention or limitation of bacterial spoilage of fermented beverages such as beer using bacteriophages is poorly studied [17]. To date, the genome sequences of approximately $50 \mathrm{Lb}$. brevis strains (and their associated prophages) are available on the NCBI database while only one lytic phage (SA-C12) [17] and one temperate phage (LBR48) have been described [19]. Here, we report the isolation and characterization of phages active against $L b$. brevis strains in order to increase our understanding of the diversity and therapeutic potential of $L b$. brevis phages.

\section{Materials and Methods}

\subsection{Bacterial Strains and Cultivation Media}

The Lactobacillus brevis strains used in this study are listed in Table 1. Bacterial stock cultures were stored in $20 \%$ glycerol at $-80^{\circ} \mathrm{C}$. Bacteria and phages were cultured and/or propagated in MRS broth (Oxoid Ltd., Hampshire, UK) at $30^{\circ} \mathrm{C}$ without agitation. MRS broth was supplemented with $10 \mathrm{mM}$ $\mathrm{CaCl}_{2}$ (Sigma-Aldrich, St. Louis, MO, USA) where appropriate. Soft agar was prepared with MRS broth supplemented with $0.4 \%$ agar and $0.5 \%$ glycine [20].

Table 1. Lactobacillus brevis strains used for phage isolation and characterisation.

\begin{tabular}{cc}
\hline Lactobacillus brevis Strains & Isolation Source \\
\hline ATCC367 [21] & Silage \\
UCCLBBS124 & Beer \\
UCCLB521 & Brewery \\
UCCLB556 & Brewery \\
SA-C12 & Silage \\
UCCLBBS449 & Beer \\
UCCLB94 & Beer \\
UCCLB95 & Beer \\
RIBM 2-56 & Beer \\
\hline
\end{tabular}

\subsection{Phage Isolation and Enrichment}

Environmental samples were clarified by centrifugation at $4000 \times g$ for $10 \mathrm{~min}$ followed by filtration through a $0.45 \mu \mathrm{m}$ filter (Sarsted, Nümbrecht, Germany) and stored at $4{ }^{\circ} \mathrm{C}$ until required. The filtrate was added to equal amounts of MRS broth supplemented with $10 \mathrm{mM} \mathrm{CaCl}_{2}$ and inoculated with an early log-phase host culture (Table 1). After incubation at $30^{\circ} \mathrm{C}$ overnight, the culture was centrifuged at $4000 \times g$ for $10 \mathrm{~min}$. This enrichment procedure was repeated twice. The filtered sample was then evaluated for the presence of phages active against a panel of Lb. brevis strains (Table 1). Each of the 
environmental samples were enriched and tested separately on each of the $L b$. brevis strains listed in Table 1.

\subsection{Phage Detection, Purification and Host Range Analysis}

The spot test method was applied in first instance to detect the presence of phages [20]. Soft agar $(4 \mathrm{~mL})$ was seeded with $200 \mu \mathrm{L}$ of fresh overnight culture and poured onto an MRS agar plate supplemented with $10 \mathrm{mM} \mathrm{CaCl}_{2}$ and $0.5 \%$ glycine. On the lawn of the series of $L b$. brevis strains, $10 \mu \mathrm{L}$ of the enriched samples was spotted and incubated at $30{ }^{\circ} \mathrm{C}$ overnight. The presence of phages was demonstrated by the presence of a clear zone on the plate. Presumptive positive samples were confirmed by plaque assay using the double-layer agar plate method [20]. A $10 \mu \mathrm{L}$ volume of the appropriate phage dilution and $200 \mu \mathrm{L}$ of $L b$. brevis culture were added to $4 \mathrm{~mL}$ of soft agar supplemented with $10 \mathrm{mM} \mathrm{CaCl}$, mixed and poured onto an MRS agar plate supplemented with $10 \mathrm{mM} \mathrm{CaCl}$ and $0.5 \%$ glycine. The plate was incubated at $30^{\circ} \mathrm{C}$ overnight and resulting plaques were enumerated. Phages were purified by single-plaque isolation using an appropriate $L b$. brevis host strain. A single plaque was picked from the bacterial lawn, transferred into a tube containing $10 \mathrm{~mL}$ MRS broth, $10 \mathrm{mM} \mathrm{CaCl} 2$ and $1 \%$ inoculum of the propagating $\mathrm{Lb}$. brevis culture. The tube was incubated at $30{ }^{\circ} \mathrm{C}$ overnight. The phage lysate was centrifuged at $4000 \times g$ for $10 \mathrm{~min}$ at $4{ }^{\circ} \mathrm{C}$. The supernatant was filtered $(0.45 \mu \mathrm{m})$ and stored at $4{ }^{\circ} \mathrm{C}$ until required. Host range studies were performed using the spot and plaque assay techniques as described above where phage lysates were tested against available $L b$. brevis strains (Table 1). The presence or absence of plaque formation was recorded indicating the susceptibility of $L b$. brevis strains to isolated phages. Plaques were enumerated and phage titre determined as plaque-forming units (PFU/mL).

\subsection{Phage Concentration and Purification}

A $2 \mathrm{~L}$ phage lysate was centrifuged at $5000 \times g$ for $10 \mathrm{~min}, 0.5 \mathrm{M} \mathrm{NaCl}$ was added to the supernatant and incubated for $1 \mathrm{~h}$ at $4{ }^{\circ} \mathrm{C}$. The preparation was centrifuged at $5000 \times g$ for $10 \mathrm{~min}$ and phages were precipitated by adding 10\% (w/v) polyethylene glycol 8000 (Sigma-Aldrich) and incubated overnight at $4{ }^{\circ} \mathrm{C}$. Phages were harvested by centrifugation (as described above) and resuspended in $4 \mathrm{~mL} \mathrm{SM}$ buffer (50 mM Tris- $\mathrm{HCl}$ pH 7.5, $100 \mathrm{mM} \mathrm{NaCl}, 10 \mathrm{mM} \mathrm{MgSO}_{4}$ ). Phages were extracted with chloroform (1:1 phage suspension:chloroform) applying multiple extraction steps where necessary (typically two or three times). The phage lysate was purified on a discontinuous $\mathrm{CsCl}$ (Sigma-Aldrich) gradient [22] and dialyzed against phage buffer (50 mM Tris- $\mathrm{HCl}, 100 \mathrm{mM} \mathrm{NaCl}, 8 \mathrm{mM} \mathrm{MgSO}$ ) overnight at $4{ }^{\circ} \mathrm{C}$.

\subsection{Transmission Electron Microscopy}

Purified bacteriophage lysates were analysed by electron microscopy, as previously described [23]. Negative staining was performed using 2\% $(w / v)$ uranyl acetate on freshly prepared ultrathin carbon films. Grids were analysed in a Tecnai 10 transmission electron microscope (FEI Thermo Fisher Scientific, Eindhoven, The Netherlands) at an acceleration voltage of $80 \mathrm{kV}$. Micrographs were taken with a MegaView G2 charge-coupled device camera (Emsis, Muenster, Germany).

\subsection{Phage DNA Extraction and Sequencing}

Phage DNA was extracted using the Norgen Biotek Corp phage DNA isolation kit as per the manufacturer's instructions (Norgen Biotek Corp., Thorold, Ontario, Canada). Phage genome sequencing was performed by GenProbio at the University of Parma, Italy. Genomes were sequenced with Illumina MiSeq Sequencing System and assembled with MIRA v4.0.2. De novo sequence assemblies and automated gene calling was performed using the MEGAnnotator pipeline [24] and assessed for predicted transfer RNA genes via tRNAscan-SE v1.2.1 [25]. Predicted open reading frames (ORFs) were determined via Prodigal v2.6 [26]. A BLASTP [27] analysis was performed to assign functional annotations to the predicted ORFs (https://blast.ncbi.nlm.nih.gov/Blast.cgi). The proposed functional annotations were further investigated by performing structural homology searches via HHpred [28] 
and querying the NCBI Conserved Domain Database (https://www.ncbi.nlm.nih.gov/Structure/cdd/ wrpsb.cgi). The annotated genomes were manually inspected, edited and finalized using the Artemis visualization tool [29].

\subsection{Phage Structural Proteome and Mass-Spectrometry}

An aliquot $(30 \mu \mathrm{L})$ of $\mathrm{CsCl}$-purified phage sample was mixed with $10 \mu \mathrm{L}$ of SDS loading buffer containing $50 \mathrm{mM} \beta$-mercaptoethanol. The structural protein profile was generated by standard Tris-glycine sodium dodecyl sulfate (SDS)-12\% polyacrylamide gel electrophoresis (PAGE). Gel slices were then excised, trypsinized, and analysed using electrospray ionisation tandem mass spectrometry (ESI-MS/MS), as previously described [30].

\subsection{Proteomic Tree}

To study the relationship between Lactobacillus phages a proteomic tree was constructed. The genomes of the five $L b$. brevis phages isolated as part of this study as well as all Lactobacillus phage genomes available on the NCBI database were downloaded. All predicted protein-encoding sequences were extracted and concatenated beginning with the ORF encoding for the small terminase subunit (TerS) [23]. The concatenated sequences were aligned using ClustalW [31]. The phylogenetic tree was constructed using the neighbour-joining method and bootstrapped employing 1000 replicates. The final tree was visualized using MEGA7 [32].

\subsection{Phage Activity against Lb. brevis Beer-Spoiling Strains}

To assess if the isolated phages could affect $L b$. brevis beer-spoiling strains' ability to grow, the strains were grown in MRS broth until an $\mathrm{OD}_{600 \mathrm{~nm}}$ of 0.2 was reached, at which point phages were added at a MOI (Multiplicity Of Infection) of 1, along with $10 \mathrm{mM} \mathrm{CaCl}$. The optical density at $600 \mathrm{~nm}$ $\left(\mathrm{OD}_{600 \mathrm{~nm}}\right)$ was recorded at 30-min intervals for $48 \mathrm{~h}$ to monitor the impact of the addition of phages on the growth of $L b$. brevis beer-spoiling strains. A control culture was also employed where the strain was grown in the absence of phage lysate but treated identically in all other aspects, i.e., filtered MRS broth was added in place of phage lysate. Addition of calcium chloride, incubation time and temperature were identical for both scenarios.

Adsorption assays were adapted from a previously outlined protocol [33]. Briefly, strains were grown to mid-late exponential phase $\left(\mathrm{OD}_{600 \mathrm{~nm}} \sim 0.5\right)$, at which point they were harvested by centrifugation at $4000 \times g$ for $10 \mathrm{~min}$ and resuspended in 1/4-strength Ringer's solution. Phages were added to the cells at a final titre of $10^{6} \mathrm{PFU} / \mathrm{mL}$ followed by incubation at $30{ }^{\circ} \mathrm{C}$ for $15 \mathrm{~min}$. The supernatant was retained after centrifugation and tested for the residual phage concentration by plaque assay as described above. Adsorption efficiency was calculated using the formula:

$$
((\mathrm{Ci}-\mathrm{Cr}) / \mathrm{Ci}) \times 100
$$

where $\mathrm{Ci}$ represents the total phage concentration used in the adsorption assay and Cr represents the residual phage concentration after the adsorption step.

The ability of phages to propagate and multiply within the host cell was also tested. $L b$. brevis strains were grown to mid-late exponential phase $\left(\mathrm{OD}_{600 \mathrm{~nm}} \sim 0.5\right)$, at which point phages were added to the culture (T0), the mix was further incubated at $30^{\circ} \mathrm{C}$ overnight (T1). The phage titre was enumerated at $\mathrm{T} 0$ and $\mathrm{T} 1$ to assess phage propagation efficiency.

\subsection{Nucleotide Sequence Accession Numbers}

The genome sequences of the phages isolated in this study were deposited in the GenBank database under accession numbers: 3-521: MK504444; 521B: MK504443; 3-SAC12: MK504442; SAC12B: MK504446; ATCCB: MK504445. The GenBank accession numbers of phage genome sequences applied in the proteomic tree preparation are as follows: Lactobacillus plantarum phage ATCC8014-B1: 
JX486087; Lactobacillus plantarum phage ATCC8014-B2: JX486088; Lactobacillus casei prophage A2: AJ251789; Lactobacillus helveticus phage AQ113: HE956704; Lactobacillus delbrueckii phage c5: EU340421; Lactobacillus casei phage J-1: KC171646; Lactobacillus delbrueckii phage JCL1032: EU409559; Lactobacillus gasseri phage kc5a: DQ320509; Lactobacillus paracasei phage Lb3381: FJ822135; Lactobacillus brevis phage LBR48: GU967410; Lactobacillus rhamnosus phage Lc-Nu: AY131267; Lactobacillus delbrueckii phage Ld3: KJ564038; Lactobacillus delbrueckii phage Ld17: KJ654037; Lactobacillus delbrueckii phage Ld25A: KJ654036; Lactobacillus delbrueckii phage Ldl1: KM514685; Lactobacillus fermentum phage LF1: HQ141410; Lactobacillus delbrueckii phage LL-H: EF455602; Lactobacillus delbrueckii phage LL-Ku: AY739900; Lactobacillus johnsonii phage Lj965: AY459535; Lactobacillus johnsonii phage Lj928: AY459533; Lactobacillus plantarum phage LP65: AY682195; Lactobacillus rhamnosus phage Lrm1: EU246945; Lactobacillus jensenii phage Lv1: EU871039; Lactobacillus gasseri phage phiadh: AJ131519; Lactobacillus casei phage phiAT3: AY605066; Lactobacillus plantarum phage phig1e: X98106; Lactobacillus delbrueckii phage phiJB: KF188409; Lactobacillus delbrueckii phage phiLdb: KF188410; Lactobacillus fermentum phage phiPYB5: GU323708; Lactobacillus casei phage PL1: KC171647; Lactobacillus brevis phage SA-C12: KU052488 and Lactobacillus plantarum phage Sha1: HQ141411.

\section{Results}

\subsection{Phage Isolation and Host Range Profile}

Lactobacillus brevis is a persistent problem in the brewing industry due to its ability to grow in, and spoil, beer. Therefore, a screen for phages capable of infecting $L b$. brevis strains with potential industrial relevance was undertaken. In excess of 200 environmental samples were screened for the presence of phages active against $L b$. brevis. These environmental samples included silage, fermented foods and wastewater samples, collected at different locations (Ireland, Belgium and The Netherlands) over a period of three years. Five distinct virulent phages capable of infecting one or more $L b$. brevis strain(s) within our collection were isolated from two different Irish wastewater samples (collected in 2017 and 2018), purified and characterised. Two phages were isolated that infected each of two strains, namely $L b$. brevis UCCLB521 and $L b$. brevis SA-C12, while a further isolate was identified that targeted Lb. brevis ATCC 367. These isolates were propagated to a titre of $10^{9} \mathrm{PFU} / \mathrm{mL}$ (except for ATCCB, where only a titre of $10^{7} \mathrm{PFU} / \mathrm{mL}$ could be reached) and applied to a host range analysis (Table 2) against the collection of $L b$. brevis strains available. This analysis highlighted the narrow host range of the isolated phages, while also highlighting the relative sensitivity of two strains. The Lb. brevis strains UCCLB521 and SA-C12 exhibited sensitivity to three and two phages, respectively. On Lb. brevis strains UCCLBBS449, UCCLB95 and RIBM 2-56, a clearing zone was observed on bacterial lawns used in the spot assay technique. However, propagation of the phages using these $L b$. brevis strains as hosts was not possible (see results below).

Table 2. $L b$. brevis phage host range analysis.

\begin{tabular}{|c|c|c|c|c|c|c|c|c|c|c|}
\hline & & \multicolumn{4}{|c|}{$L b$. brevis Non-Beer Spoiling Strains } & \multicolumn{5}{|c|}{$L b$. brevis Beer-Spoiling Strains } \\
\hline \multirow{3}{*}{ Phage } & $521 \mathrm{~B}$ & - & $+^{*}$ & - & - & - & $\sim$ & - & - & - \\
\hline & 3-SAC12 & - & - & - & $+^{*}$ & - & - & - & - & - \\
\hline & SAC12B & - & + & - & $+^{*}$ & - & - & - & - & $\sim$ \\
\hline
\end{tabular}

+: strain susceptible to phage infection; -: strain resistant to phage infection; $\sim$ : clearing zone was observed; *: host strain.

\subsection{Phage Morphology}

The morphological diversity of the phage isolates was assessed by transmission electron microscopy (Figure 1). Lb. brevis phages 3-521, SAC12B and 521B possessed relatively short yet wide contractile 
tails and a large icosahedral head with a large complex baseplate structure at the distal end of the tail (Figure 1). These structural features are consistent with the typical attributes of Myoviridae phages [34] and revealed morphological similarity to the only virulent $L b$. brevis phage identified to date, SA-C12 [17]. Lb. brevis phage 3-SAC12 possessed an icosahedral head, a defined baseplate structure and a long decorated contractile tail (Figure 1) and, therefore, also belongs to the Myoviridae family [34] and resembles the $L b$. brevis temperate phage LBR48 [19]. Lb. brevis phage ATCCB was classified as a Siphoviridae phage due to the presence of a long non-contractile tail, a large icosahedral head and a discrete baseplate at the tip of the tail (Figure 1).

A.

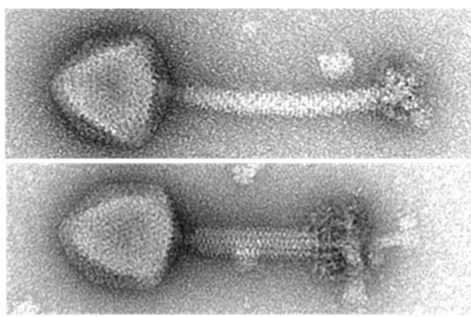

B.

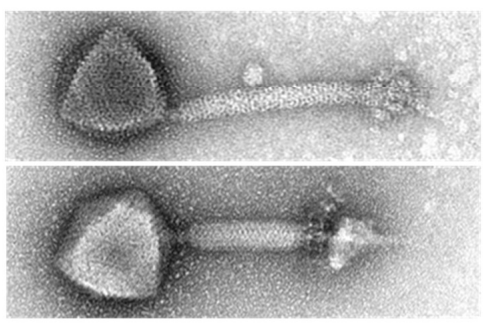

C.

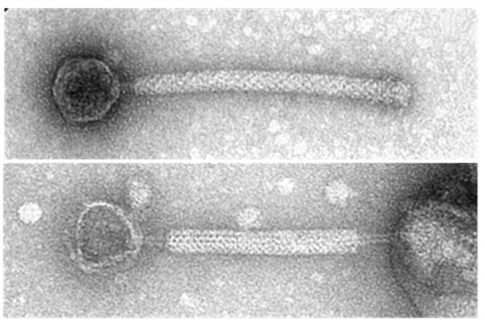

D.

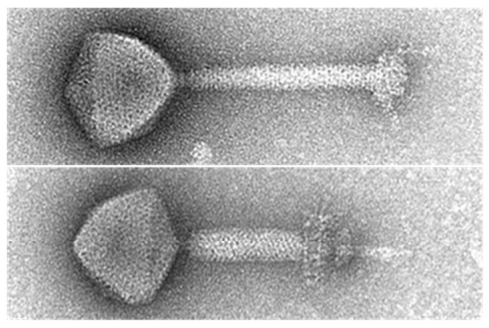

E.

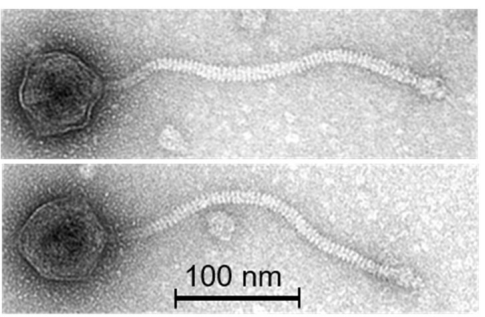

\begin{tabular}{ccc}
\hline $\begin{array}{c}\text { Head } \\
\text { diameter }\end{array}$ & Tail length* $^{*}$ & Tail width \\
\hline 95.3 & 201.9 & 21.8 \\
$\pm 4.2 \mathrm{~nm}$ & $\begin{array}{c} \pm 5.0 \mathrm{~nm} \\
(\mathrm{n}=9)\end{array}$ & $\begin{array}{c} \pm 0.9 \mathrm{~nm} \\
(\mathrm{n}=9)\end{array}$ \\
\hline
\end{tabular}

* Incl. baseplate structures, when present

\begin{tabular}{ccc}
\hline $\begin{array}{c}\text { Head } \\
\text { diameter }\end{array}$ & Tail length* $^{*}$ & Tail width \\
\hline 87.1 & 201.0 & 20.5 \\
$\pm 2.8 \mathrm{~nm}$ & $\pm 0.3 \mathrm{~nm}$ & $\pm 0.5 \mathrm{~nm}$ \\
$(\mathrm{n}=2)$ & $(\mathrm{n}=2)$ & $(\mathrm{n}=2)$ \\
\hline
\end{tabular}

* Incl. baseplate structures, when present

\begin{tabular}{ccc}
\hline $\begin{array}{c}\text { Head } \\
\text { diameter }\end{array}$ & Tail length* & Tail width \\
\hline 58.3 & 237.8 & 17.9 \\
$\pm 2.0 \mathrm{~nm}$ & $\begin{array}{c} \pm .6 \mathrm{~nm} \\
(\mathrm{n}=10)\end{array}$ & $\begin{array}{c} \pm 0.8 \mathrm{~nm} \\
(\mathrm{n}=12)\end{array}$ \\
\hline
\end{tabular}

\begin{tabular}{ccc}
\hline $\begin{array}{c}\text { Head } \\
\text { diameter }\end{array}$ & Tail length* & Tail width \\
\hline 98.5 & 187.9 & 23.2 \\
$\pm 1.2 \mathrm{~nm}$ & $\pm 3.0 \mathrm{~nm}$ & $\begin{array}{c} \pm 0.7 \mathrm{~nm} \\
(\mathrm{n}=4)\end{array}$ \\
\hline
\end{tabular}

* Incl. baseplate structures, when present

\begin{tabular}{ccc}
\hline $\begin{array}{c}\text { Head } \\
\text { diameter }\end{array}$ & Tail length* & Tail width \\
\hline 70.8 & 288.4 & 12.3 \\
$\pm 2.7 \mathrm{~nm}$ & $\pm 8.4 \mathrm{~nm}$ & $\begin{array}{c} \pm 0.4 \mathrm{~nm} \\
(\mathrm{n}=11)\end{array}$ \\
\hline
\end{tabular}

Figure 1. Electron micrographs of lytic Lb. brevis phages 3-521 (A), 521B (B), 3-SAC12 (C), SAC12B (D) and ATCCB (E). Head diameter, tail length and width are also indicated, where " $\mathrm{n}$ " represents the number of phage particles measured. For phage 521B and SAC212B, only few particles were detected with original extended tail sheaths (i.e., 2-4 particles). Tail lengths of phages 3-521, 521-B and SAC12B are also including the complex baseplate structures. 


\subsection{Lb. brevis Phages Comparative Analysis and Grouping}

In order to evaluate the diversity of $L b$. brevis phages and their phylogenetic links to phages of other lactobacilli, a proteomic tree was created gathering the five $L b$. brevis phages characterized in this study as well as all previously sequenced Lactobacillus phages (Figure 2). The phylogenetic tree shows an interesting organization based seemingly on morphology rather than phage infecting-species. The right side of the tree displays exclusively phages belonging to the Siphoviridae family, while the left side predominantly gathered phages belonging to the Myoviridae family. It is noteworthy that $L b$. brevis phages are quite diverse as they do not form a single cluster and are, in fact, spread across the phylogenetic tree with the exception of phages SAC12B and 521B, which form a clade next to the Lb. helveticus phage AQ113, a Myoviridae phage which shows similarity to phages of human gut-inhabiting species [35]. Lb. brevis phages 3-521, 3-SAC12, SA-C12, ATCCB and LBR48 all gathered closely on the tree in between $L b$. plantarum phages 8014-B1, 8014-B2 and Lb. delbrueckii phage JCL1032, highlighting once again the interrelationships of the Lactobacillus phages. The relationship between these phages infecting similar host species might be explained by evolution over time from a common ancestor $[23,36]$.

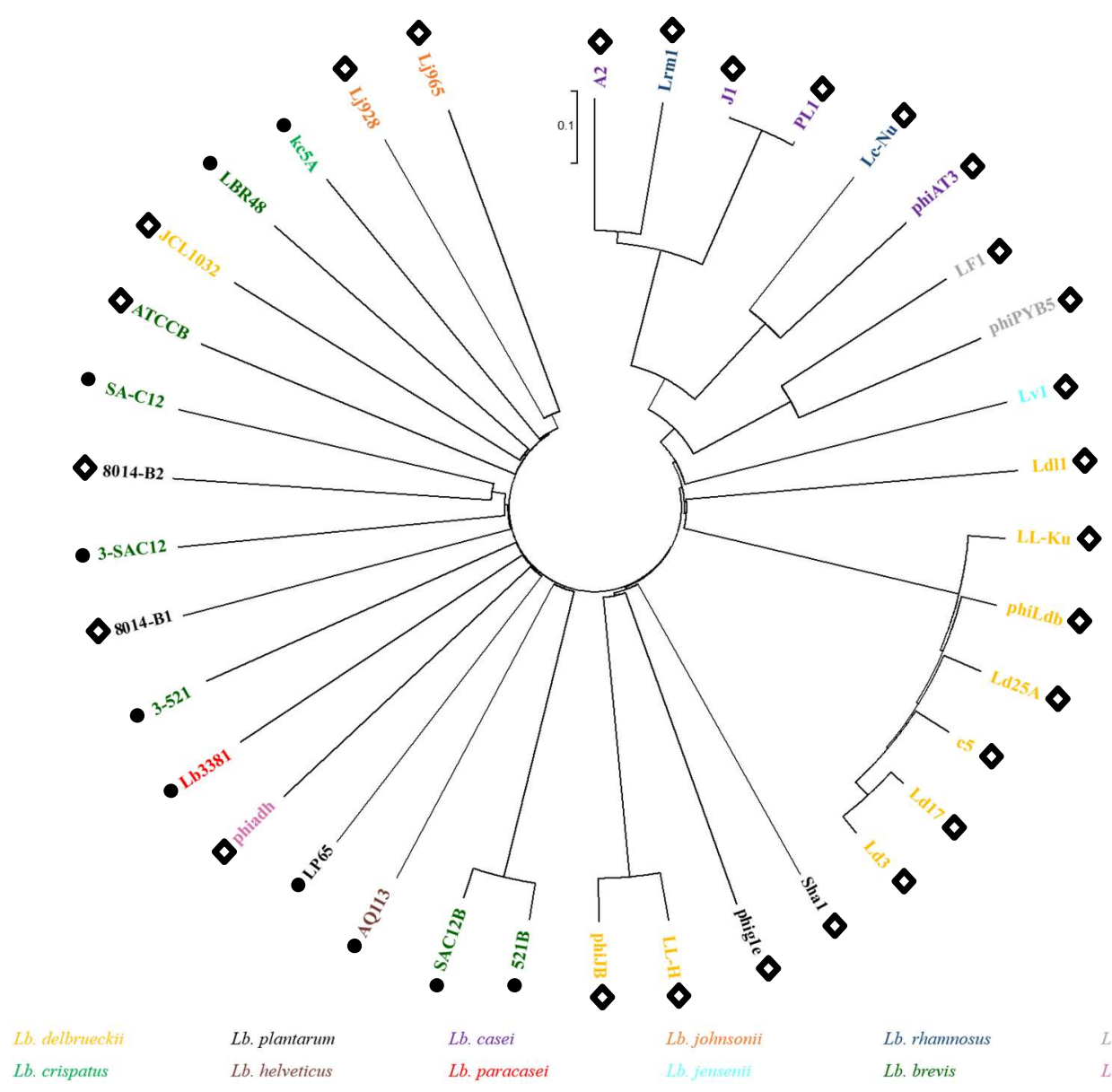

Figure 2. Proteomic tree of all Lactobacillus phages sequenced to date. Colour coding indicates the host species for each phage. Black circles indicate Myoviridae phages, while white diamonds indicate Siphoviridae phages.

\subsection{Genome Analysis}

Genomic DNA of the five lytic phages was isolated and sequenced revealing significant genetic disparity between these phages. General genome characteristics of the phage isolates are summarized in Table 3. The Siphoviridae phage ATCCB possesses a genome of $80.5 \mathrm{~kb}$ while the Myoviridae phage 
genomes vary in size from $\sim 41-141 \mathrm{~kb}$ (Table 3). The largest phage genome among the isolates is that of 3-521 with a genome of $140.8 \mathrm{~kb}$, which now represents the largest known $L b$. brevis phage genome sequenced to date. Interestingly, the $L b$. brevis myophages SAC12B, 521B and 3-521 are more closely related to myophages of other Lactobacillus spp. harbouring a large genome size, such as $L b$. casei Lb338-1 (142 kb) [37] and Lb. plantarum LP65 (131 kb) [38], than the previously characterized Lb. brevis phages (LBR48 and SA-C12) (Figure 2).

Table 3. General characteristics of $L b$. brevis phages.

\begin{tabular}{|c|c|c|c|c|c|c|c|}
\hline & Phage & $\begin{array}{l}\text { Sample } \\
\text { (Date) }\end{array}$ & $\begin{array}{l}\text { Isolation } \\
\text { Source }\end{array}$ & $\begin{array}{l}\text { Genome } \\
\text { Size (bp) }\end{array}$ & ORFs & $\begin{array}{c}\text { GC Content } \\
(\%)\end{array}$ & $\begin{array}{l}\% \text { nt Identity } \\
\text { (\% coverage) }\end{array}$ \\
\hline \multirow{4}{*}{ Myoviridae } & $3-521$ & S1 (2017) & $\begin{array}{l}\text { Wastewater } \\
\text { (Ireland) }\end{array}$ & 140,816 & 155 & 36.93 & \\
\hline & $521 \mathrm{~B}$ & S2 (2018) & $\begin{array}{l}\text { Wastewater } \\
\text { (Ireland) }\end{array}$ & 136,442 & 188 & 32.27 & $\begin{array}{l}97 \text { (88) with } \\
\text { SAC12B }\end{array}$ \\
\hline & SAC12B & S2 (2018) & $\begin{array}{l}\text { Wastewater } \\
\text { (Ireland) }\end{array}$ & 136,608 & 191 & 32.41 & $\begin{array}{c}97 \text { (88) with } \\
521 \mathrm{~B}\end{array}$ \\
\hline & 3-SAC12 & S1 (2017) & $\begin{array}{l}\text { Wastewater } \\
\text { (Ireland) }\end{array}$ & 41,292 & 61 & 40.01 & \\
\hline Siphoviridae & ATCCB & S2 (2018) & $\begin{array}{l}\text { Wastewater } \\
\text { (Ireland) }\end{array}$ & 80,538 & 96 & 30.80 & \\
\hline
\end{tabular}

The genome of the phages investigated here display limited/no similarity to each other or to the genomes of other $L b$. brevis phages, with the exception of phages 521B and SAC12B. These two phages share $97 \%$ nucleotide sequence identity ( $88 \%$ coverage) and their close relationship may be the result of their cohabitation within the same environment, as they were both isolated from the same wastewater sample in 2018 (Table 3). The absence of similarity with previously described $L b$. brevis phages highlights the limited knowledge, and the apparent genetic diversity of these phages. The GC content of the phages is relatively low (Table 3$)$ compared to that of the host $(\sim 46 \%)$, implying that they may have evolved recently to infect $L b$. brevis strains. The genomes of phages 3-521, 521B and SAC12B appear complex due to their size and their high number of predicted ORFs but present a similar genome organization. The genomes were organised into four functional modules: DNA packaging, morphogenesis, DNA replication and lysis modules (Figure 3A). For phages 3-SAC12 and ATCCB, the genome organization is similar but with a lysis module preceding the replication module (Figure 3B,C). While these phage isolates are predicted to be obligatorily virulent, there are traces of temperate ancestry in some of their genomes. For example, phage 3-SAC12 possesses a predicted antirepressor-encoding gene (typically associated with lytic/lysogenic switch genomic regions) while ATCCB possesses a predicted recombinase/integrase-encoding gene [23]. 

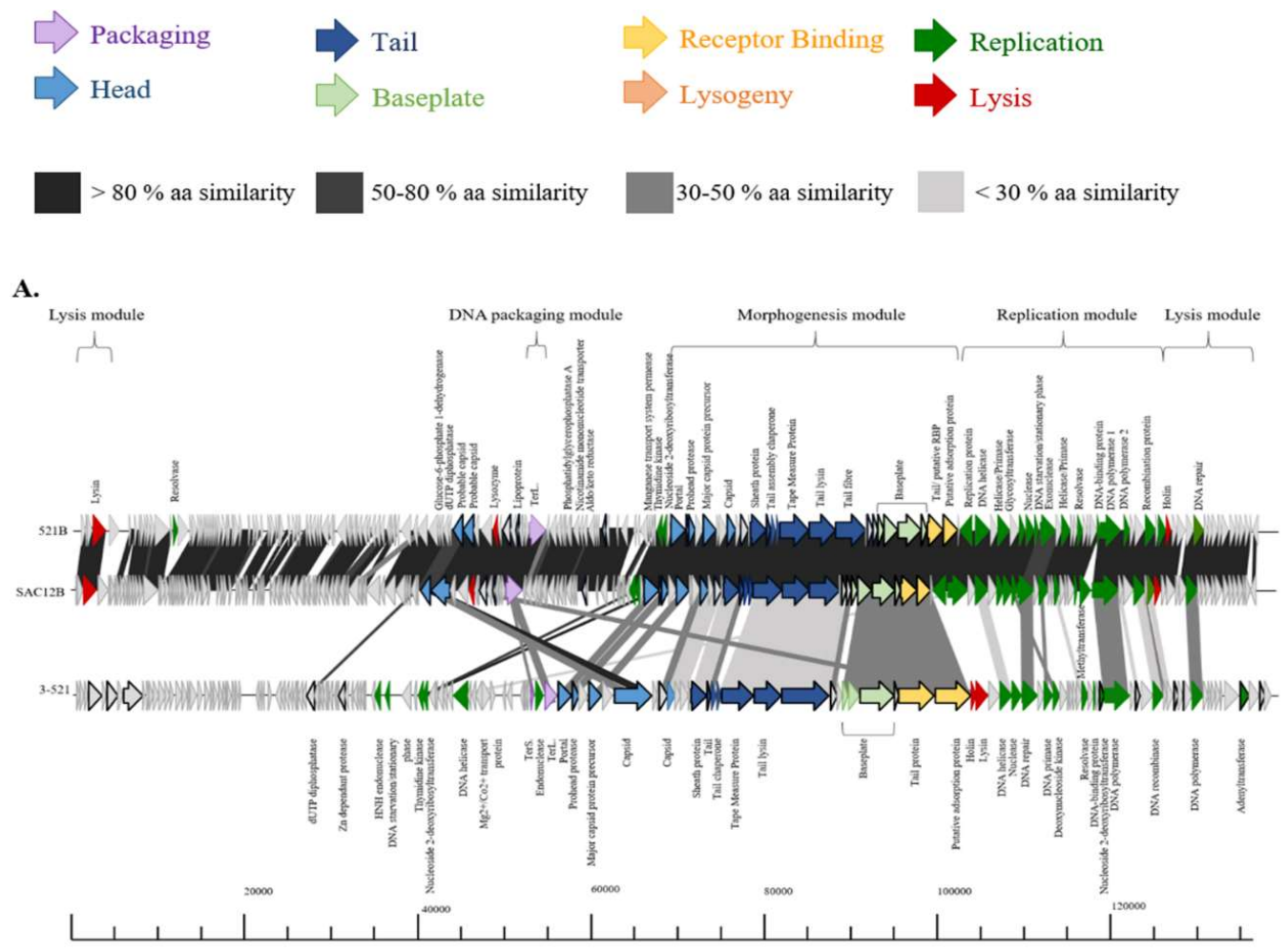

B.
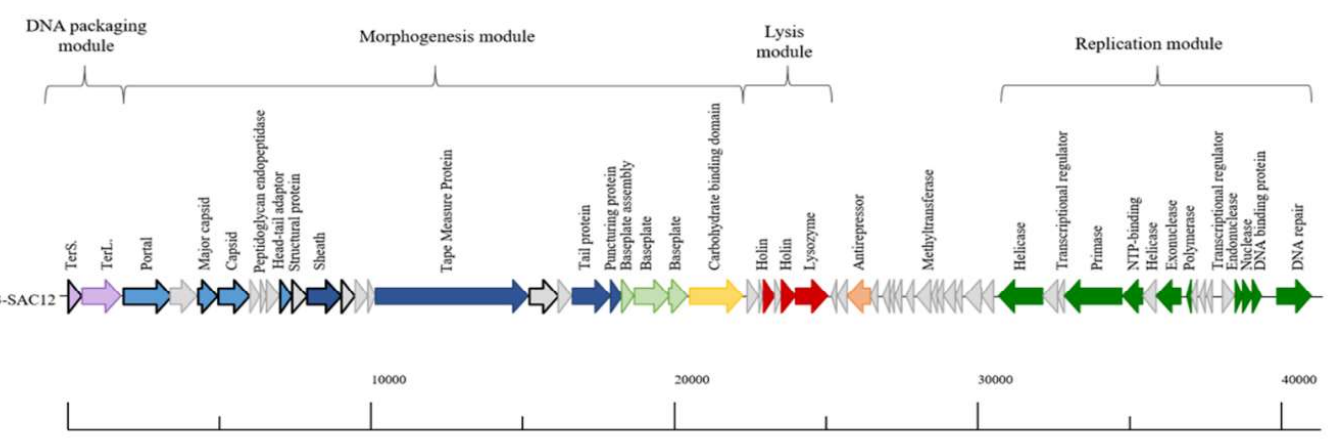

C.

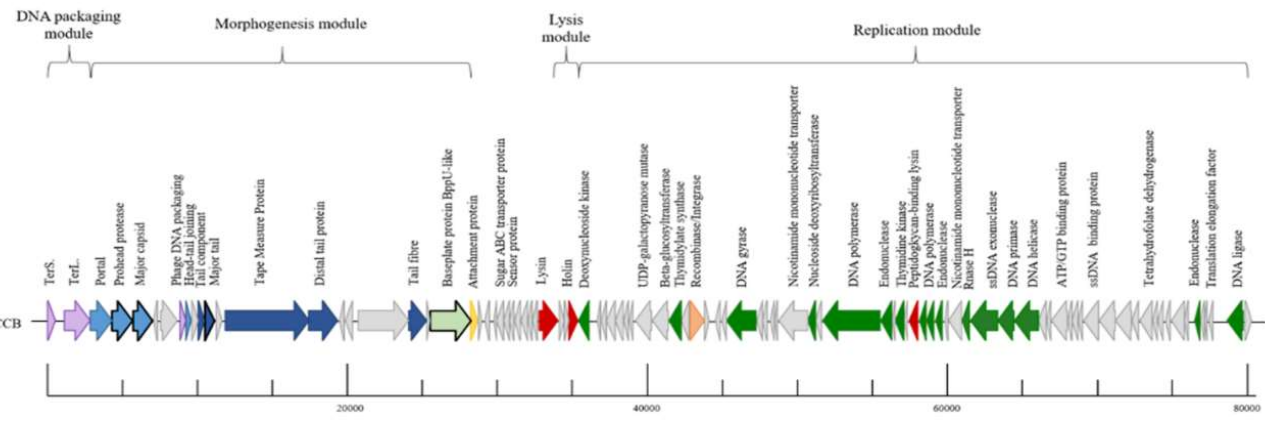

Figure 3. Genomic organisation of lytic Lb. brevis phages 3-521, 521B and SAC12B (A), 3-SAC12 (B) and ATCCB (C). The scale at the bottom of genomes is in base pairs. Each arrow represents an ORF, with the colour representing the putative function of the encoded protein. Confirmed structural protein-encoding genes from mass spectrometry analysis are also highlighted (bold outline). TerS. Small terminase subunit, TerL. Large terminase subunit. 


\subsection{Morphogenesis Module}

The majority of the morphogenesis modules of $L b$. brevis phages $3-521,521 \mathrm{~B}$ and SAC12B exhibited a high degree of synteny in the region encoding the portal protein through to the putative adsorption protein (Figure 3A). Phages 521B and SAC12B share more than $90 \%$ amino acid (aa) sequence identity, while 3-521 shares less than $50 \%$ aa sequence similarity with 521B and SAC12B across the morphogenesis module (Figure 3A). The most notable difference is the apparent insertion of an additional capsid-encoding protein in 3-521. The encoded predicted capsid protein, ORF573-521, is divided in two different proteins in $521 \mathrm{~B}$ (ORF $80_{521 \mathrm{~B}}$-ORF $81_{521 \mathrm{~B}}, 90 \%$ and $45 \%$ aa similarity, respectively) and in SAC12B (ORF79 ${ }_{\mathrm{SAC} 12 \mathrm{~B}}-\mathrm{ORF} 80_{\mathrm{SAC} 12 \mathrm{~B}}, 26 \%$ and $83 \%$ aa similarity). In $521 \mathrm{~B}$ and SAC12B, these protein-encoding genes are located upstream of the DNA packaging module in a divergently oriented cluster of genes of unknown function. Interestingly, it suggests the fusion of two ancestral phages into these two unique phages: 521B and SAC12B (Figure 3A).

The morphogenesis module of the Myoviridae Lb. brevis phage 3-SAC12 harbours genes encoding the phage capsid and tail structural components including a portal protein, two capsid proteins and a head-tail adaptor protein, the tail sheath protein, a tail tape measure protein (TMP), the major tail protein (MTP) and a "puncturing device" protein. This puncturing device comprises the tip of the central spike and is proposed to facilitate DNA ejection into the host cell [39]. Furthermore, at the distal tail region, there is a large organelle described as a baseplate complex that comprises three structural proteins (ORF21 3 -SAC12, ORF22 $3-\mathrm{SAC} 12$ and ORF233-SAC12) and a protein that harbours a predicted carbohydrate binding domain (ORF24 3 -SAC12) that we predict to bind to the host cell acting as the receptor binding protein (RBP) (Figure $3 \mathrm{~B}$ ).

The Siphoviridae phage ATCCB appears less complex in its morphogenesis module compared to the Myoviridae phages and genes encoding a portal protein, a prohead protease, a major capsid protein, a head-tail joining protein, four predicted tail proteins, a distal tail (Dit) protein, a tail fibre protein, a baseplate protein and a predicted attachment protein, assumed to be involved in host recognition and binding, were identified (Figure 3C).

\subsection{Structural Proteome}

The lytic $L b$. brevis phages were analysed by mass spectrometry to identify their structural proteomes (Table 4). Most of the predicted proteins encoded within the morphogenesis module of the genomes of 521B, SAC12B and 3-521 were confirmed as structural proteins with the predicted portal protein, prohead protease, major capsid precursor protein, capsid protein, tail sheath protein, tail proteins, tape measure protein, tail lysin, tail fibre, baseplate proteins, putative receptor binding protein and adsorption protein; all identified as structural proteins using this approach (Table 4 and Figure 3A). The majority of the predicted structural proteins forming the capsid and the tail components were identified in 3-SAC12 and ATCCB (Table 4, Figure 3B,C). Some (presumed) structural proteins were not identified in the experimentally determined proteome, which was likely due to their small size or their low relative abundance. 
Table 4. Structural proteins extracted from purified phage particles by ESI-MS/MS. A minimum of two independent unique peptides or $5 \%$ coverage were used as threshold values.

\begin{tabular}{|c|c|c|c|c|}
\hline Phage & ORF & Putative Function & No. of Peptides & Sequence Coverage (\%) \\
\hline \multirow[t]{25}{*}{ 521B } & 80 & Probable capsid protein & 8 & 29.4 \\
\hline & 81 & Probable capsid protein & 9 & 28.4 \\
\hline & 86 & Structural protein & 3 & 16.1 \\
\hline & 88 & Lipoprotein & 5 & 50.8 \\
\hline & 106 & Structural protein & 4 & 37.9 \\
\hline & 121 & Portal protein & 12 & 28.3 \\
\hline & 122 & Structural protein & 2 & 17.4 \\
\hline & 123 & Caudovirus prohead protease & 4 & 20.8 \\
\hline & 125 & Major capsid protein precursor & 19 & 59.7 \\
\hline & 128 & Capsid protein & 3 & 16.8 \\
\hline & 130 & Gp91 & 8 & 35 \\
\hline & 132 & Major tail sheath protein & 16 & 40.4 \\
\hline & 133 & Tail protein & 5 & 59.9 \\
\hline & 136 & Tape measure protein & 28 & 31.2 \\
\hline & 137 & Tail lysin & 12 & 15.1 \\
\hline & 138 & Structural component of the tail fibre & 8 & 10 \\
\hline & 140 & Structural protein & 2 & 15.1 \\
\hline & 141 & Structural protein & 5 & 42.2 \\
\hline & 142 & Baseplate protein & 3 & 23.1 \\
\hline & 143 & Baseplate J-like protein & 6 & 15.1 \\
\hline & 144 & Baseplate protein & 7 & 9.4 \\
\hline & 146 & Tail protein & 15 & 34.1 \\
\hline & 147 & Putative adsorption protein & 9 & 22.2 \\
\hline & 156 & $\begin{array}{c}\text { DNA starvation/stationary phase } \\
\text { protein }\end{array}$ & 6 & 48 \\
\hline & 185 & Structural protein & 3 & 38.5 \\
\hline \multirow[t]{26}{*}{ 3-521 } & 10 & dUTP diphosphatase & 2 & 9.9 \\
\hline & 19 & Zn-dependent protease & 5 & 23.7 \\
\hline & 52 & Portal protein & 3 & 7.9 \\
\hline & 53 & Prohead protease & 1 & 8.3 \\
\hline & 55 & Major capsid protein & 19 & 51.1 \\
\hline & 57 & Phage capsid and scaffold & 19 & 18.6 \\
\hline & 60 & Structural protein & 4 & 20.1 \\
\hline & 65 & Tail sheath protein & 14 & 25 \\
\hline & 66 & Putative tail protein & 6 & 53.3 \\
\hline & 69 & Tape measure protein & 14 & 17.4 \\
\hline & 70 & Tail lysin protein & 16 & 21.1 \\
\hline & 71 & gp673 & 2 & 1.7 \\
\hline & 72 & Structural protein & 3 & 15.3 \\
\hline & 76 & Baseplate protein & 4 & 3 \\
\hline & 77 & Structural protein & 2 & 18 \\
\hline & 78 & Tail protein & 22 & 24.5 \\
\hline & 79 & Tail associated protein & 23 & 20.1 \\
\hline & 98 & Nucleoside 2-deoxyribosyltransferase & 2 & 12.4 \\
\hline & 101 & Structural protein & 1 & 6.1 \\
\hline & 106 & Structural protein & 7 & 62 \\
\hline & 108 & Tail protein & 1 & 18 \\
\hline & 117 & Adenyltransferase & 6 & 16.9 \\
\hline & 119 & ADP-ribose pyrophosphatase & 1 & 5.3 \\
\hline & 124 & Structural protein & 6 & 15.7 \\
\hline & 126 & AAA superfamily ATPase & 9 & 26.2 \\
\hline & 128 & Phosphatase & 4 & 5.4 \\
\hline \multirow[t]{9}{*}{ 3-SAC12 } & 1 & Terminase small subunit & 1 & 6.6 \\
\hline & 3 & Portal protein & 13 & 31.4 \\
\hline & 5 & Major capsid protein & 4 & 26.3 \\
\hline & 6 & Capsid protein & 9 & 26.7 \\
\hline & 10 & Putative head-tail adaptor & 1 & 9.8 \\
\hline & 11 & Structural protein & 1 & 9 \\
\hline & 12 & Sheath protein & 3 & 11.8 \\
\hline & 13 & Structural protein & 2 & 22.4 \\
\hline & 17 & Structural protein & 4 & 13.6 \\
\hline \multirow[t]{4}{*}{ АТССВ } & 70 & Baseplate protein & 6 & 9.2 \\
\hline & 79 & Major tail protein & 6 & 50.2 \\
\hline & 86 & Major capsid protein & 8 & 25.9 \\
\hline & 87 & Prohead protease & 2 & 7.5 \\
\hline
\end{tabular}




\subsection{Phage Activity against Lb. brevis Beer-Spoiling Strains}

Phage adsorption experiments were performed in order to test the ability of the phages to recognize and bind to $L b$. brevis beer-spoiling strains. Here, an adsorption efficiency higher than $50 \%$ was considered as significantly effective adsorption of the phage to the strain. Phages were tested against all $L b$. brevis beer-spoiling strains and efficient phage adsorption was only observed in the cases described below (Figure 4D-F). Adsorption of the lytic phages 521B and 3-521 to their Lb. brevis host UCCLB521 showed more than 90\% adsorption efficiency. Phages 521B and 3-521 were capable of high adsorption efficiencies to the Lb. brevis strains UCCLBBS449 and UCCLB95 $(86.6 \pm 4.7 \%$ and $98.9 \pm 0.5 \%$, respectively). Similarly, SAC12B adsorbed to its host strain SA-C12 and the beer-spoiling strain RIBM 2-56, with similar efficiencies $(90.9 \pm 0.9 \%$ versus $87.7 \pm 0.0 \%)$. Lb. brevis strain UCCLBBS124 was not adsorbed efficiently by phages 3-521 and SAC12B (Figure 4E,F) and even if 521B showed an adsorption efficiency of $66.6 \pm 7.0 \%$ on UCCLBBS124 (Figure 4D), no infection or effect of the phage was observed against this strain (Figure S1). Since most of the phages were capable of adsorbing to $L b$. brevis beer-spoiling strains, experiments were performed to study their ability to affect growth of $L b$. brevis strains in nutritive media (MRS broth). Lb. brevis beer-spoiling strains were grown in nutritive media until they reached an $\mathrm{OD}_{600 \mathrm{~nm}}$ of 0.2 , at which point the relevant lytic phage showing adsorption capability (Figure $4 \mathrm{D}-\mathrm{F}$ ) were added to reach an MOI of 1 . In some cases, the addition of the bacteriophage to the culture had a negative effect on growth of the $L b$. brevis beer-spoiling strain, as the strains were not able to grow after addition of the phages even after $32 \mathrm{~h}$ of exposure (Figure 4A-C). Lytic phages 521B, 3-521 and SAC12B were shown to affect growth of $L b$. brevis strains UCCLBBS449, UCCLB95 and RIBM 2-56, respectively (Figure 4A-C). No negative impact was observed on the growth of $L b$. brevis beer-spoiling strain UCCLBBS124 even after addition of phages and was used as a control (Figure S1). Growth curves of the host strains Lb. brevis UCCLB521 and SA-C12, with and without phage treatment, are also described in Figure S1.

Lytic phages isolated as part of this study adsorb onto $L b$. brevis beer-spoiling strains and negatively affect their growth. However, they failed to form visible plaques on the beer-spoiling strains, thus we aimed to evaluate the potential of these phages to propagate within the host cell. Plaque assays after the enrichment did not reveal phage propagation and multiplication within the host (data not shown) as the phage titre did not increase after the incubation period. However, while they did not infect the beer-spoiling strains, they did appear to affect the growth rate of $L b$. brevis beer-spoiling strains. It did not seem that the phages propagate lytically on these strains, but the negative impact of phages on certain $L b$. brevis beer-spoiling strains might be caused by a high-multiplicity phage adsorption and/or by the action of exogenous phage-encoded lysin on the bacteria [40].

The negative impact of phages on $L b$. brevis strains growth presents potential for the application of such entities to control bacterial spoilage of beer. In the experiment presented above, the number of cells to which phages were added is high and most certainly exceeds levels encountered during the beer fermentation process. 
A.

UCCLBBS449

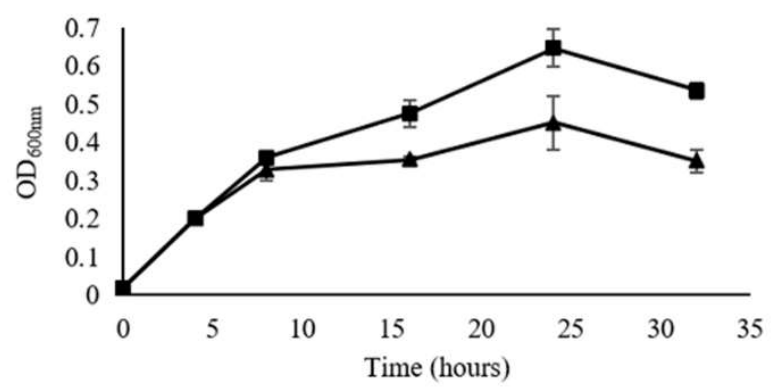

$\rightarrow-U C C L B B S 449 \rightarrow-U C C L B B S 449+$ phage 521B

B.

UCCLB95

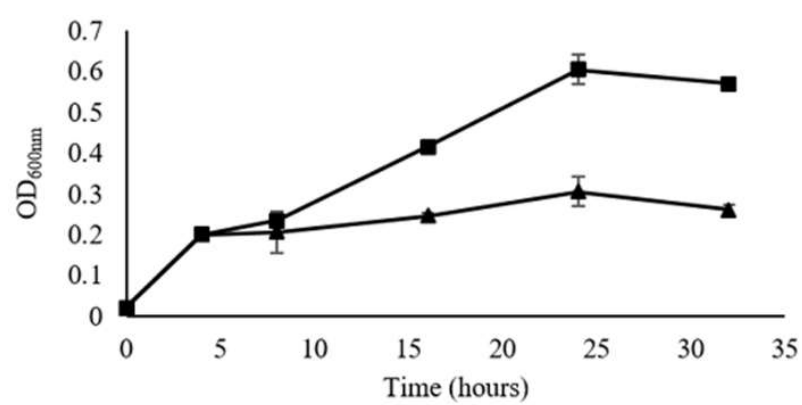

$\rightarrow$ UCCLB95 $\rightarrow$ UCCLB95 + phage 3-521

C.

RIBM 2-56

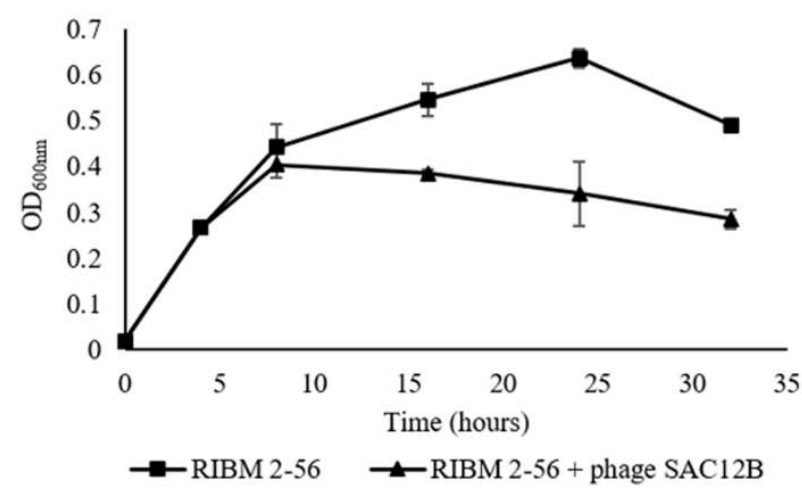

D.

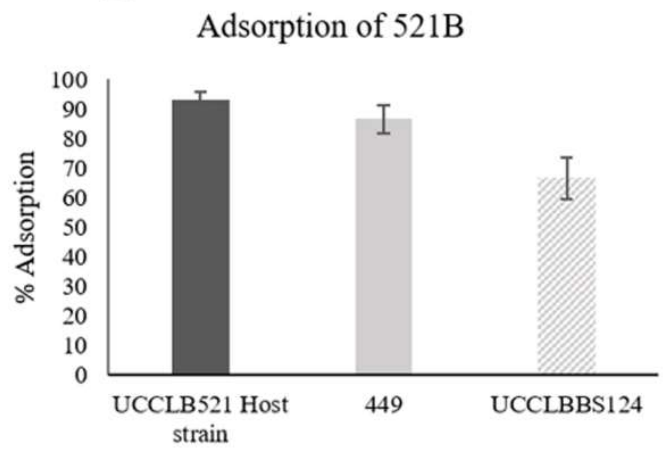

E.

Adsorption of 3-521

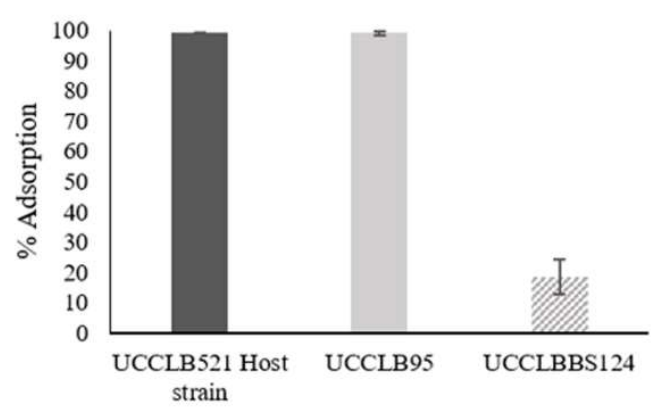

F.

Adsorption of SAC12B

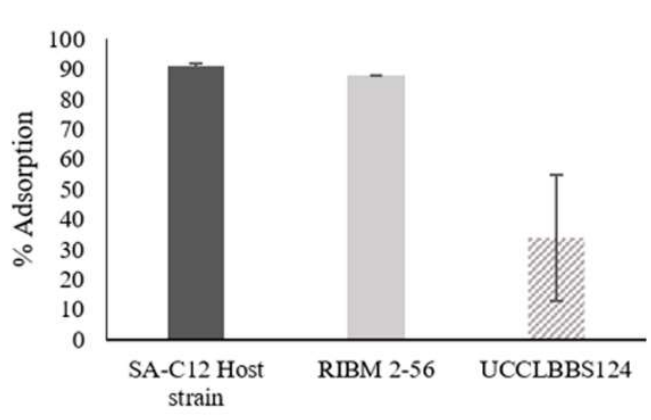

Figure 4. (A-C) Growth of $L b$. brevis beer-spoiling strains when challenged with lytic phages (MOI = 1 when the culture reached an $\mathrm{OD}_{600 \mathrm{~nm}}$ of 0.2 ). A culture of the bacterial strain where no phage was added was used as a control. (D-F) Adsorption assays of lytic phages 521B, 3-521 and SAC12B onto $L b$. brevis strains. Respective $L b$. brevis host strains were used as positive control while $L b$. brevis UCCLBBS124 was used as a negative control.

\section{Conclusions}

In this study, the isolation and characterization of five $L b$. brevis-infecting phages considerably increases knowledge of the genetic and morphological diversity of Lb. brevis phages, as only one lytic $L b$. brevis phage had been isolated to date. Despite their shared host species, they show a high level of genetic diversity. Their morphology and genome size vary considerably with the largest phage isolated against $L b$. brevis being that of 3-521 with a genome size of $141 \mathrm{~kb}$. Some of the phages isolated 
as part of this study showed activity against $L b$. brevis beer-spoiling strains preventing them from growing optimally, thus providing new approaches to control bacterial spoilage of beer. Indeed, such phages may be used in the future during beer fermentation to control and restrain growth of spoilage bacteria by bioremediation.

Interestingly, $L b$. brevis bacteria are widely present in fermented foods, silage or microbiota; however, phages against this microorganism were not ubiquitously and easily isolated. Out of 200 environmental samples screened, only five lytic $L b$. brevis phages were retrieved and only from Irish wastewater samples, indicating the rarity and the hurdle of isolating such entities. The study of $L b$. brevis phages is in its infancy and many questions remain to be answered regarding their mode of action and their evolutionary strategies. For this reason, screening of phage populations from different sources is necessary to provide sufficient knowledge for their potential use in bioremediation applications.

Supplementary Materials: The following are available online at http://www.mdpi.com/1999-4915/11/5/393/s1, Figure S1: Growth of (A) Lb. brevis beer-spoiling strain UCCLBBS124, (B) Lb. brevis strain UCCLB521 and (C) $L b$. brevis strain SA-C12 when challenged with lytic phages (MOI $=1$ when the culture reached an $\mathrm{OD}_{600 \mathrm{~nm}}$ of 0.2 ). A culture of the bacterial strain where no phage was added was used as a control.

Author Contributions: M.F. performed experiments, annotation, genomic and proteomic analysis. G.A.L. and M.V. carried out sequence assembly and annotation. H.N. and C.M.A.P.F. carried out electron microscopy analysis. J.-P.N. performed mass-spectrometry analysis. D.v.S., J.M., T.O.S. provided materials and strains. M.F., J.M., T.O.S. and D.v.S. were involved in project design and wrote the manuscript. All authors read and approved the final manuscript.

Funding: Marine Feyereisen is the recipient of an Irish Research Council Enterprise Partnership Scheme postgraduate scholarship (Ref. No. EPSPG/2015/7). Douwe van Sinderen is supported by a Principal Investigator award (Ref. No. 450 13/IA/1953) through Science Foundation Ireland (SFI). Jennifer Mahony is in receipt of the Starting Investigator Research Grant (SIRG) (Ref. No. 15/SIRG/3430) funded by Science Foundation Ireland (SFI).

Acknowledgments: The authors are grateful to Dagmar Matoulková of the Research Institute of Brewing and Malting, Prague, who kindly provided Lb. brevis RIBM 2-56. The authors also acknowledge the technical help of Angela Back (Max Rubner-Institut, Kiel) in the electron microscopic analysis.

Conflicts of Interest: The authors declare that T.O.S. is an employee of Heineken.

\section{References}

1. Vos, P.; Garrity, G.; Jones, D.; Krieg, N.R.; Ludwig, W.; Rainey, F.A.; Schleifer, K.-H.; Whitman, W. Bergey's Manual of Systematic Bacteriology Volume 3: The Firmicutes; Springer Science and Business Media: Athens, GA, USA, 2011; pp. 464-511.

2. Salvetti, E.; Torriani, S.; Felis, G.E. The genus Lactobacillus: A taxonomic update. Probiotics Antimicrob. Proteins 2012, 4, 217-226. [CrossRef]

3. Felis, G.E.; Dellaglio, F. Taxonomy of Lactobacilli and Bifidobacteria. Curr. Issues Intest. Microbiol. 2007, 8, 44-61.

4. Bergsveinson, J.; Pittet, V.; Ewen, E.; Baecker, N.; Ziola, B. Genome sequence of rapid beer-spoiling isolate Lactobacillus brevis BSO 464. Genome Announce. 2015, 3, e01411-e01415. [CrossRef]

5. Sakamoto, K.; Konings, W.N. Beer spoilage bacteria and hop resistance. Int. J. Food Microbiol. 2003, 89, 105-124. [CrossRef]

6. Suzuki, K.; Iijima, K.; Sakamoto, K.; Sami, M.; Yamashita, H. A review of hop resistance in beer spoilage lactic acid bacteria. J. Institute Brewing 2006, 112, 173-191. [CrossRef]

7. Vaughan, A.; O'Sullivan, T.; van Sinderen, D. Enhancing the microbiological stability of malt and beer-A review. J. Institute Brewing 2005, 111, 355-371. [CrossRef]

8. Bokulich, N.A.; Bamforth, C.W. The Microbiology of malting and brewing. Microbiol. Mol. Biol. Rev. 2013, 77, 157-172. [CrossRef]

9. Back, W.; Leibhard, M.; Bohak, I. Flash pasteurisation-membrane filtration. Biological security in comparison. Brauwelt Int. 1990, 12, 42-49.

10. Davidson, P.M.; Harrison, M.A. Resistance and adaptation to food antimicrobials, sanitizers, and other process controls. Food Technol. 2002, 56, 69-78. 
11. Basanta, A.; Sánchez, J.; Gómez-Sala, B.; Herranz, C.; Hernández, P.E.; Cintas, L.M. Antimicrobial activity of Enterococcus faecium L50, a strain producing enterocins L50 (L50A and L50B), P and Q, against beer-spoilage lactic acid bacteria in broth, wort (hopped and unhopped), and alcoholic and non-alcoholic lager beers. Int. J. Food Microbiol. 2008, 125, 293-307. [CrossRef]

12. Gil, G.; del Monaco, S.; Cerrutti, P.; Galvagno, M. Selective antimicrobial activity of chitosan on beer spoilage bacteria and brewing yeasts. Biotechnol. Lett. 2004, 26, 569-574. [CrossRef]

13. Vaughan, A.; Rouse, S.; van Sinderen, D. Investigating the antimicrobial efficacy of a Lactococcal bacteriocin for the development of microbiologically stable beer. J. Institute Brewing 2004, 110, 181-188. [CrossRef]

14. Mahony, J.; McAuliffe, O.; Ross, R.P.; van Sinderen, D. Bacteriophages as biocontrol agents of food pathogens. Curr. Opin. Biotechnol. 2011, 22, 157-163. [CrossRef]

15. Coffey, B.; Mills, S.; Coffey, A.; McAuliffe, O.; Ross, R.P. Phage and their lysins as biocontrol agents for food safety applications. Annual Rev. Food Sci. Technol. 2010, 1, 449-468. [CrossRef]

16. Endersen, L.; O’Mahony, J.; Hill, C.; Ross, R.P.; McAuliffe, O.; Coffey, A. phage therapy in the food industry. Annual Rev. Food Sci. Technol. 2014, 5, 327-349. [CrossRef]

17. Deasy, T.; Mahony, J.; Neve, H.; Heller, K.J.; van Sinderen, D. Isolation of a virulent Lactobacillus brevis phage and its application in the control of beer spoilage. J. Food Protect. 2011, 74, 2157-2161. [CrossRef]

18. Brüssow, H.; Desiere, F. Comparative phage genomics and the evolution of Siphoviridae: Insights from dairy phages. Mol. Microbiol. 2001, 39, 213-222. [CrossRef]

19. Jang, S.H.; Yoon, B.H.; Chang, H.I. Complete nucleotide sequence of the temperate bacteriophage LBR48, a new member of the family Myoviridae. Archi. Virol. 2011, 156, 319-322. [CrossRef]

20. Svensson, U.; Christiansson, A. Methods for phage monitoring. Bulletin Inter. Dairy Federation 1991, 263, 29-39.

21. Makarova, K.; Slesarev, A.; Wolf, Y.; Sorokin, A.; Mirkin, B.; Koonin, E.; Pavlov, A.; Pavlova, N.; Karamychev, V.; Polouchine, N.; et al. Comparative genomics of the lactic acid bacteria. Proc. Nat. Acad. Sci. USA 2006, 103, 15611-15616. [CrossRef]

22. Sambrook, J.; Russell, D.W. Purification of bacteriophage $\lambda$ particles by isopycnic centrifugation through $\mathrm{CsCl}$ gradients. Cold Spring Harbor Protocols 2006, 1, pdb-prot3968. [CrossRef]

23. Casey, E.; Mahony, J.; Neve, H.; Noben, J.-P.; Dal Bello, F.; van Sinderen, D. Novel phage group infecting Lactobacillus delbrueckii subsp. lactis, as revealed by genomic and proteomic analysis of bacteriophage Ldl1. Appl. Environ. Microbiol. 2015, 81, 1319-1326. [CrossRef]

24. Lugli, G.A.; Milani, C.; Mancabelli, L.; van Sinderen, D.; Ventura, M. MEGAnnotator: A user-friendly pipeline for microbial genomes assembly and annotation. FEMS Microbiol. Lett. 2016, 363. [CrossRef]

25. Lowe, T.M.; Eddy, S.R. tRNAscan-SE: A program for improved detection of transfer RNA genes in genomic sequence. Nucleic Acids Res. 1997, 25, 955-964. [CrossRef] [PubMed]

26. Hyatt, D.; Chen, G.-L.; LoCascio, P.F.; Land, M.L.; Larimer, F.W.; Hauser, L.J. Prodigal: Prokaryotic gene recognition and translation initiation site identification. BMC Bioinformat. 2010, 11, 119. [CrossRef]

27. Altschul, S.F.; Madden, T.L.; Schaffer, A.A.; Zhang, J.; Zhang, Z.; Miller, W.; Lipman, D.J. Gapped BLAST and PSI-BLAST: A new generation of protein database search programs. Nucleic Acids Res. 1997, 25, 3389-3402. [CrossRef]

28. Soding, J.; Biegert, A.; Lupas, A.N. The HHpred interactive server for protein homology detection and structure prediction. Nucleic Acids Res. 2005, 33, W244-W248. [CrossRef]

29. Rutherford, K.; Parkhill, J.; Crook, J.; Horsnell, T.; Rice, P.; Rajandream, M.A.; Barrell, B. Artemis: sequence visualization and annotation. Bioinformatics 2000, 16, 944-945. [CrossRef]

30. Holtappels, M.; Vrancken, K.; Schoofs, H.; Deckers, T.; Remans, T.; Noben, J.-P.; Valcke, R. A comparative proteome analysis reveals flagellin, chemotaxis regulated proteins and amylovoran to be involved in virulence differences between Erwinia amylovora strains. J. Proteomics 2015, 123, 54-69. [CrossRef]

31. Thompson, J.D.; Gibson, T.J.; Higgins, D.G. Multiple sequence alignment using ClustalW and ClustalX. Curr. Protocols Bioinformat. 2003, 1, 2-3. [CrossRef] [PubMed]

32. Kumar, S.; Nei, M.; Dudley, J.; Tamura, K. MEGA: A biologist-centric software for evolutionary analysis of DNA and protein sequences. Briefings Bioinformat. 2008, 9, 299-306. [CrossRef] [PubMed]

33. Collins, B.; Bebeacua, C.; Mahony, J.; Blangy, S.; Douillard, F.P.; Veesler, D.; Cambillau, C.; van Sinderen, D. Structure and functional analysis of the host recognition device of lactococcal phage Tuc2009. J. Virol. 2013, 87, 8429-8440. [CrossRef] [PubMed] 
34. Matthews, R.E.F.; Maurin, J. Classification and nomenclature of viruses. Ann. Microbiol. 1979, 1, $133-136$. [CrossRef]

35. Zago, M.; Scaltriti, E.; Rossetti, L.; Guffanti, A.; Armiento, A.; Fornasari, M.E.; Grolli, S.; Carminati, D.; Brini, E.; Pavan, P.; et al. Characterization of the genome of the dairy Lactobacillus helveticus bacteriophage ФAQ113. Appl. Environment. Microbiol. 2013, 79, 4712-4718. [CrossRef]

36. Tuohimaa, A.; Riipinen, K.-A.; Brandt, K.; Alatossava, T. The genome of the virulent phage Lc-Nu of probiotic Lactobacillus rhamnosus, and comparative genomics with Lactobacillus casei phages. Archi. Virol. 2006, $151,947$. [CrossRef] [PubMed]

37. Alemayehu, D.; Ross, R.P.; O'Sullivan, O.; Coffey, A.; Stanton, C.; Fitzgerald, G.F.; McAuliffe, O. Genome of a virulent bacteriophage Lb338-1 that lyses the probiotic Lactobacillus paracasei cheese strain. Gene 2009, 448, 29-39. [CrossRef]

38. Chibani-Chennoufi, S.; Dillmann, M.-L.; Marvin-Guy, L.; Rami-Shojaei, S.; Brüssow, H. Lactobacillus plantarum bacteriophage LP65: A new member of the SPO1-like genus of the family Myoviridae. J. Bacteriol. 2004, 186, 7069-7083. [CrossRef]

39. Rossmann, M.G.; Mesyanzhinov, V.V.; Arisaka, F.; Leiman, P.G. The bacteriophage T4 DNA injection machine. Curr. Opin. Struct. Biol. 2004, 14, 171-180. [CrossRef]

40. Abedon, S.T. Lysis from without. Bacteriophage 2011, 1, 46-49. [CrossRef]

(C) 2019 by the authors. Licensee MDPI, Basel, Switzerland. This article is an open access article distributed under the terms and conditions of the Creative Commons Attribution (CC BY) license (http://creativecommons.org/licenses/by/4.0/). 